\title{
The Persecuted Black Lechwe of Zambia
}

\author{
R.H.V. Bell and J.J.R. Grimsdell
}

The black lechwe of northern Zambia are today confined entirely to one area, the Bangweulu floodplain. Numbers have shrunk from more than half-a-million as recently as $\mathbf{5 0}$ years ago to an estimated 16,000 today. The authors, who have been engaged in a $3 \frac{1}{2}$-year research project on these lechwe, are able to show that the numbers today are well below the carrying capacity of the floodplains, and that poaching is the cause. The highly specialised lechwe is the only mammal capable of exploiting the high fertility of the floodplain, which could support ten times the present numbers. Allowed to increase and properly managed on sustained yield principles, the black lechwe could provide a large quantity of badly needed protein in Zambia.

The lechwe Kobus leche is the characteristic antelope of the great Central African floodplains, and each of the three major floodplain systems holds a distinct subspecies. The nominate subspecies, the red lechwe Kobus leche leche occurs in small scattered populations in the drainages of the upper Zambezi, Kafue and Okavango rivers (total numbers not known); the Kafue lechwe Kobus leche kafuensis occurs in a single population of about 94.000 (Grimsdell \& Bell, 1970 ) on the Kafue Flats in southern Zambia; the black lechwe Kobus leche smithemani is confined to the Bangweulu basin in northern Zambia.

The black lechwe is physically the most distinct subspecies, being the smallest and the most divergent in colour. But it is not black. The females differ from their fox-red cousins only in a greyish tinge

Table 1 Adult liveweight data (in $\mathrm{kg}$ ) for the three lechwe subspecies in Zambia

$\begin{array}{lll}\text { Subspecies } & \begin{array}{l}\text { Adult males (4 yrs +) } \\ \text { Mean wt. (range) }\end{array} & \begin{array}{l}\text { Adult females (3 yrs }+ \text { ) } \\ \text { Mean wt. (range) }\end{array} \\ \text { Black lechwe' } & 77.4(63.9-89.2) & 62.6(53.4-71.6) \\ \text { Red lechwe }^{2} & \mathrm{n}=7 & \mathrm{n}=7 \\ & 105.5(102.4-108.7) & 59.8(- \\ \text { Kafue lechwe } & \mathrm{n}=2 & \mathrm{n}=1 \\ & 102.9(86.5-127.7) & 78.7(61.6-96.9) \\ \quad\left(\mathrm{n}=\text { sample size) }^{3}\right. & \mathrm{n}=38 & \mathrm{n}=83\end{array}$

1. Our data together with 3 records collected by W.E. Poles (quoted in Allen, 1963).

2. Records collected by W.F.H. Ansell (quoted in Allen, 1963).

3. Data from Robinette \& Child, 1964.

(to obtain weights in lbs multiply by 2.2 ) 
to their coats; the immature males closely resemble the Kafue lechwe with their russet coat marked by a stripe on the front leg expanding into a black patch on the front of the shoulder. In the adult male, however, the black shoulder patch spreads up the sides of the throat and along the bottom of the flank, eventually covering the shoulder and rump, and in very exceptional cases may converge on top of the spine; the belly and throat remain white, as do the insides of the ears, the lips and an incomplete ring around the eyes. A good adult male is a strikingly handsome animal. The extent of the black colouring seems to be generally related to age, but is very variable in a given age class. In addition, a much higher proportion of well marked males is seen during the rut; that is during the wet season, December to February, which suggests that the males change colour in relation to their reproductive status. Even so, a completely black male is exceedingly rare, and J. E. Hughes (1933) records that, in the 18 years he spent in the area in the first decades of the century, he examined only three.

\section{The Habitat}

The Bangweulu basin (map opposite) is a shallow depression in the plateau of northern Zambia, with a level floor of about $160 \mathrm{~km}(100$ miles) diameter, fed by 16 rivers, the largest of which is the Chambeshi but with only one outlet, the Luapula. In the wet season the inflow exceeds the capacity of the Luapula to drain it, and the water level rises by several feet, so that, towards the end of the rains, the whole floor of the basin is inundated with shallow water. At this time most of the alluvium from the very large catchment is dropped in the basin, so that the rich peats of the floodplain contrast strongly with the leached sandy soils of the plateau. The exceptions are the sand-bank islands that line the main river channels and form the sites of permanent villages. The slopes of the basin are blanketed by the uniform, sparsely settled Brachystegia woodland of the plateau, but the floor vegetation is determined by the position in relation to the flooding regime.

The annual flooding is the dominant feature of the environment, and the distribution of plants, animals and human activity are clearly zoned in relation to it. Flood levels have been measured since 1956 , and the records show that the pattern varies slightly from year to year, local water depths apparently being controlled by rainfall within the floodplain and in the immediate catchments. However, there is good evidence that, in the 1930s, the general water level of the whole swamp and lake area rose by several feet, and did not return to its former level (Brelsford, 1944 \& 1946). This rise was not related to any trend in the local rainfall, and must have been caused by some change in the flow properties within the basin. It had a large impact on the ecology of the basin.

The north-west quarter of the basin floor is occupied by open lakes, the largest of which is Lake Bangweulu, while the centre is filled by a large ( $2600 \mathrm{sq} . \mathrm{km} ; 1000 \mathrm{sq}$. miles) triangle of permanent swamp bordered on three sides by the great floodplain, covering 


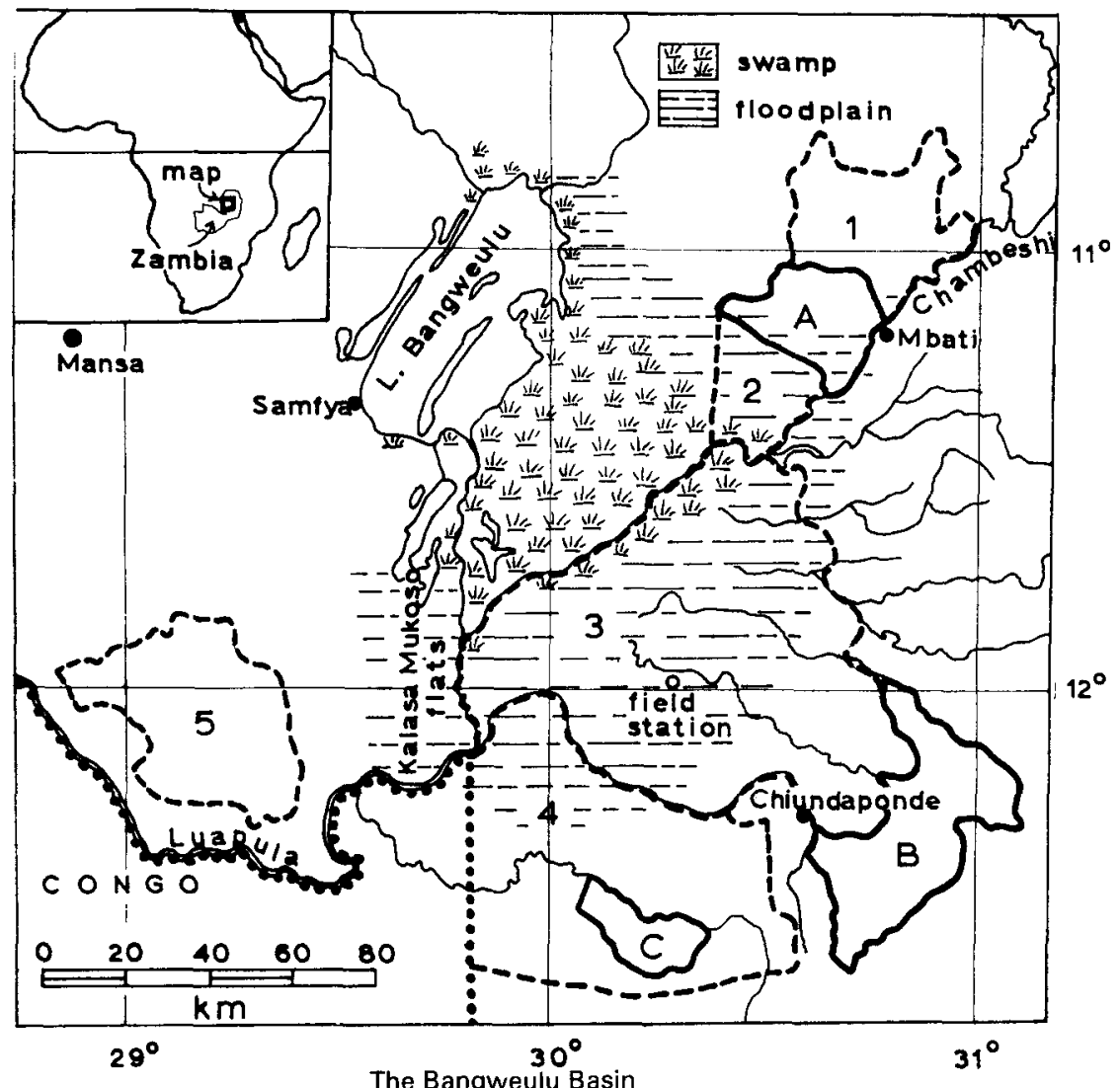

The Bangweulu Basin

National Parks: A, Isangano; B, Lavushi Manda; C, Kasanka. Game Management Areas: 1, Luwingu; 2, Chambeshi; 3, Bangweulu; 4, Kafinda; 5, Mansa about 10,000 sq. $\mathrm{km}$. (4000 sq. miles) that is the principal lechwe habitat: it is subdivided into three zones in relation to water depth:

1. The deep water floodplain, parts of which remain permanently flooded, dominated by floating mat grasses that collapse as the floods recede-Oryza barthii, Echinochloa stagnina, Vossia cuspidata, etc, with the sedges Eleocharis and Cyperus spp.

2. The peripheral grasslands, inundated to about $45 \mathrm{cms}$ (18 ins) at the height of the floods, with coarse upright grasses including Loudetia simplex, Setaria sphacelata, Heteropogon contortus, Themeda triandra, etc.

3. The watermeadow grasslands, occupying small pockets between the two previous grass types, flooded to about $60 \mathrm{cms}(24$ ins) at the height of the floods, with highly productive areas of short mat grasses, Acroceras macrum, Leersia hexandra, Panicum parvifolium.

A characteristic feature of the floodplain is the very large number of termitaria, ranging in diameter from a few centimetres to many metres. The large anthills in particular are important in that they provide islands during the flooding and usually support woody vegetation, and are, therefore, foci of activity for all mammal species, including man. 


\section{The Fauna}

The flooded areas and peripheral woodlands support a diverse and unusual fauna which is a major exploitable resource. Fish populations attain very high densities, exploiting the seasonal release of nutrients in the hydroponic conditions of the floodplain and swamp, and 110 species are recorded (Brelsford, 1946). Fishing in the basis of the area's economy today, being almost the only source of protein, employment and income in the flooded areas. In addition to large numbers of the commoner waterbirds, the whaleheaded stork or shoe-bill Balaeniceps rex, a species of particular interest, is locally common and has frequently been seen nesting. The basin provides the habitat for the specialised water-tolerant species of mammals and reptiles and also for the varied fauna of the peripheral grasslands and plateau woodland, but numbers of most species have been drastically reduced compared with the numbers mentioned in earlier accounts, e.g. Hughes, 1933. Most of the species listed below are scarce, and zebra, eland and rhino must be considered on the verge of local extinction.

The species are zoned as follows:

1. Swamp and channels: crocodile, hippopotamus, sitatunga.

2. Floodplain: black lechwe.

3. Peripheral grassland: tsessebe, eland, zebra, roan antelope, reedbuck, oribi.

4. Plateau woodland and drainage: Lichtenstein's hartebeest, sable antelope, waterbuck, puku, warthog, bushpig, bushbuck, grysbuck, duiker, leopard, ? black rhino.

5. Throughout, except for deepwater floodplain and swamp: elephant, buffalo, lion.

The sitatunga deserves special mention, for the Bangweulu swamp and floodplain and the marshes in the peripheral woodland must contain one of Africa's major concentrations of this elusive antelope. They can easily be seen from the air, and in some places can be watched with comparative ease on the ground. Although only a limited attempt has been made to estimate their numbers, the total is certainly in the thousands. Aerial survey by sampling of parts of the Lukulu and Lulimala rivers shows densities in suitable areas of $20-40$ animals $/ \mathrm{km}$ of river line, giving totals of 250 and 200 in the immediate vicinities of the field station and the Lulimala game camp respectively.

\section{Human Population}

The population of the north Zambian plateau originated in a series of invasions from the west by people whose ecology is based on shifting cultivation, with no knowledge of domestic stock. With each successive invasion, the remnants of the previous occupants took refuge in the inaccessible floodplains and swamps, adopting the specialised way of life this environment demands, based on fishing and hunting from temporary camps scattered on anthills and sand banks through the flooded areas, with permanent villages and cassava cultivation on the larger sand islands. 
The floodplain provides a very deficient environment, and existence depends on fishing and exchanging the catch on the mainland for clothing, implements, and wood for building, for canoes and for firewood. The key to the inhabitants' way of life is the dug-out canoe, the only practical means of transport in the floodplain. In recent years the deficiencies have become increasingly severe. Firstly, the rise in water level in the 1930s made many of the village sites and cassava gardens untenable, particularly in the central swamps. Secondly, the progressive and now almost complete removal of woody vegetation from the islands has created a severe shortage of building materials and firewood required for smoking fish; it has also led to exhaustion of the forest peat on the islands, so that the cassava, now planted in long rotation in a poor sandy soil, yields a small and declining crop. Thirdly, the meat from wild animals, particularly lechwe, formerly a major source of food, has declined drastically. Lastly, the fishery, now the major resource and indeed the largest in the country, producing an estimated 7250 metric tons a year, provides low individual incomes, due to the inefficient methods of gill netting and trapping that are the only practical techniques in the grass-filled water (Inoue, 1971). For these reasons, the people have been moving to the periphery of the floodplain, where fishing can be supplemented by shifting cultivation and villages are accessible to road transport, and the human population of the central swamp and floodplains has declined.

Nevertheless, the population density of the floodplain and its periphery is well above the national rural average, the plateau woodlands being generally extremely sparsely inhabited. In the immediate neighbourhood of the principal lechwe range there are at least 15,000 people and on the remainder of the basin floor probably a further minimum of 40,000 people.

\section{Black Lechwe Project}

For many years there has been concern about the decline of the wildlife populations of Bangweulu and particularly of the black lechwe. After various preliminary surveys, the Zambian Department of Wildlife, Fisheries and National Parks finally approached the Anglo American Corporation, who agreed to finance a research project with a very generous grant. The project, which was to last $3 \frac{1}{2}$ years, began in mid 1969 with the following objectives:

1. To determine the present numbers, distribution, and status of the black lechwe population;

2. To determine the relative influence of the rise in water level and uncontrolled hunting on the decline of the population;

3. To suggest methods by which the population can be rehabilitated and utilised to the economic benefit of the inhabitants.

The project is administered by the Zambian National Council for Scientific Research, at whose headquarters near Lusaka we have office and laboratory facilities. In the floodplain we work from a field station and airstrip built on a small island in the watermeadow 
grassland, in the centre of the lechwe's principal wet season concentration area. In addition to free access to Wildlife Department aircraft, one of which was bought with the Anglo American grant, we operate with a variety of special transport, including canoes, a 'Flextrac-Nodwell' amphibious tracked carrier, and an 'Aircat' airboat.

The black lechwe formerly occurred in large numbers in most of the floodplains of northern Zambia in addition to the Bangweulu basin, but if they still exist in some of these outlying areas, it is as scattered individuals, and the survival of the subspecies depends on the Bangweulu populations. Their history may be inferred from contemporary accounts, although we realise that unsystematic estimates of animal numbers of this sort are totally unreliable.

'The numbers of the lechwe must be seen to be believed', wrote J.E. Hughes (1933) of the years before the First World War. 'Enormous herds congregate; on the move through the shallow water, their splash is like the roar of a distant ocean'. Both Hughes and other witnesses of this period agree that large numbers occurred in areas where none or very few survive today, notably the northern floodplain and the Lunga bank, a raised area in the middle of the permanent swamp.

G. Howe (1954), a district officer stationed in the swamps in 192224 , estimated that at that time the total population could have been as many as 600,000 even following the slaughter of the First World War, when a supply route ran through the area (Marshall, 1957). 'In December 1922', he wrote, 'black lechwe were to be seen in their tens of thousands on the sides of the channel all the way from Mukuku to Nsalushi Island (about $130 \mathrm{~km} ; 80$ miles). In fact, lechwe were to be seen in every direction and when one of the vast herds started to move, the whole horizon appeared to undulate'. When he returned to the swamps in 1927 , he wrote, 'I was quite shocked to see how the herds of lechwe had diminished. I gave my opinion that, at the then rate of slaughter, it was only a matter of time before the black lechwe was exterminated'. However in 1931 the numbers were still very large. Captain C.R.S. Pitman (1934), in compiling his Faunal Survey of Northern Rhodesia, examined all the evidence then available, and estimated 150,000 for the whole population.

No further estimates were made until 1954 when the first aerial census with photography was carried out by D.F. Vesey-Fitzgerald (1955). He counted a total of about 15,000 black lechwe, indicating a very drastic reduction in the intervening 23 years. Further aerial censuses carried out in 1954 and 1959 by the Wildlife Department showing totals of about 16,000, suggested that the population had at last stabilised. But in 1966 , the observers were able to locate only 4000 lechwe. This alarming result precipitated the present research and law enforcement activity. Our own estimate, based on a series of total aerial censuses with photography since October 1969, is about 16,000 with fluctuations in relation to the calving period of August to October. 


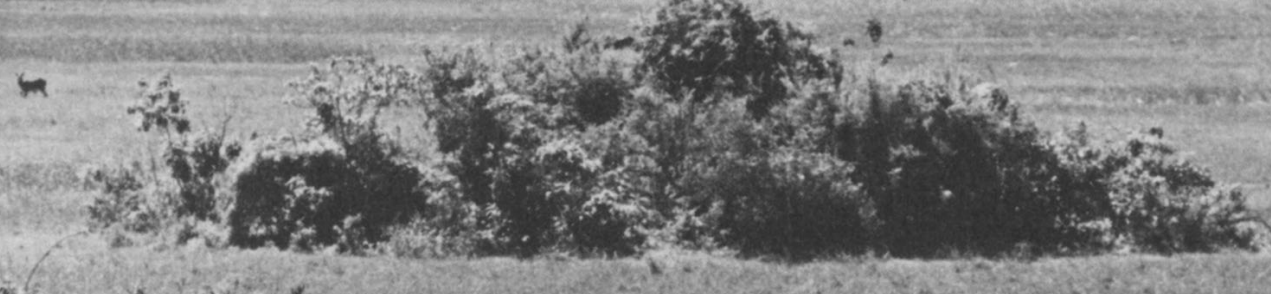
axil.

Wratax

$2.12+24$ is

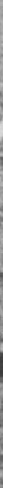

HERD OF BLACK LECHWE MALES
MIXED HERD IN FLIGHT
All photographs by J.J.R. Grimsdell

$x^{2} y^{2}$

$$
-\pi x^{2}+2
$$

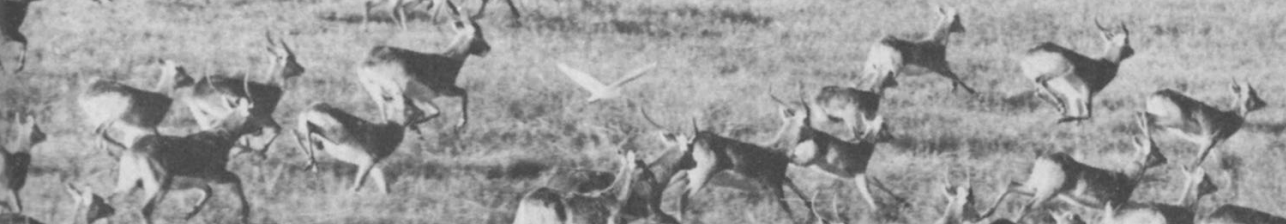

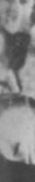

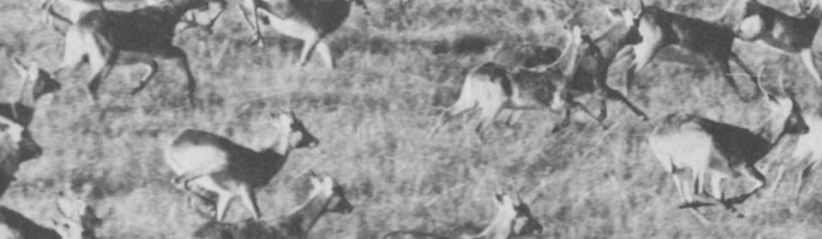


Apart from the 1966 count, these results seem superficially consistent, but, on analysis, further discrepancies emerge. The existing population is separated into four distinct sub-populations between which little interchange is possible. In the four censuses at comparable times of year, these were represented as follows:

$\begin{array}{lrrrr} & \text { April } & \text { May } & \text { May } & \text { May } \\ & 1954 & 1966 & 1970 & 1971 \\ \text { Kalasa Mukoso Flats } & 131 & 248 & 2292 & 2050 \\ \text { Southern Floodplain } & 12,539 & 3649 & 13,000 & 13,000 \\ \text { Eastern Floodplain } & 1452 & 9 & 552 & 268 \\ \text { Northern Floodplain } & 846 & 102 & 113 & \text { not flown } \\ \begin{array}{l}\text { Bwela Flats } \\ \text { (Chinsali District) }\end{array} & 100 & \text { nil } & \text { nil } & \text { not flown } \\ & & & & \end{array}$

These discrepancies call for some discussion of the aerial census problems.

At most seasons, including May, the black lechwe occur in clumped concentrations widely separated over about $10,000 \mathrm{sq} . \mathrm{km}$ (4,000 sq. miles) of floodplain, a type of distribution that is unsuitable for sample censusing. The major problem is navigation and orientation; this is accentuated in Bangweulu by the rather featureless nature of the terrain, which requires an accurate vegetation map and a thorough knowledge of the area, neither of which was available in the earlier censuses. Even with these advantages, we experienced difficulty in orientation when counting the large concentrations of the southern floodplain, and for this reason the 1970 and 1971 totals for this section are given approximately, and no trend can be ascertained for that year. But we are confident that, in the case of the two peripheral populations, Kalasa-Mukoso and the eastern floodplain, the differences between the 1970 and 1971 figures represent a real decline of about 10 per cent and 50 per cent respectively.

We therefore conclude that the population contains a minimum of 16,000 animals, but that the peripheral sections at least are declining at an appreciable rate. This conflicts both with the 1966 total and with the supposition from the earlier counts that the population had stabilised. However, for the 1966 count of 4000 to have reached 16,000 in 1969 would have required an annual increment of over 50 per cent, an impossibility in a single annual breeder with a sex ratio near unity, such as black lechwe. We therefore ignore the 1966 count as being quite unrealistic.

There are also two good reasons for believing that the earlier aerial counts were underestimates, although their totals are similar to ours, giving a false impression of population stability. Firstly, in the northern and eastern floodplains, the 1954 survey located 2298 lechwe as opposed to 665 in 1970 , a drop in numbers of about 1600 . That a decline has taken place in these areas is confirmed by a report by P. F. N. de V. Moss (pers. comm.), a former District Officer stationed at Mpika, who in 1962 saw 'more than 1000' lechwe at 


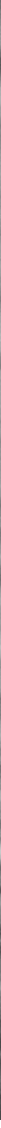

Male BLACK LECHWE, and below a SITATUNGA disturbed from his wallow by the aeroplane

W. A.

MHa

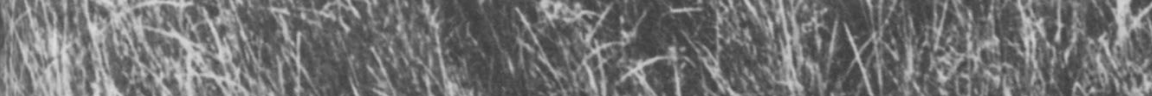

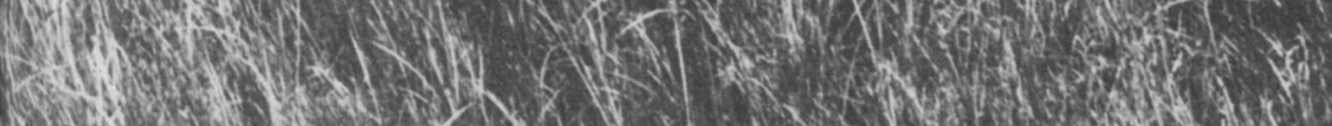

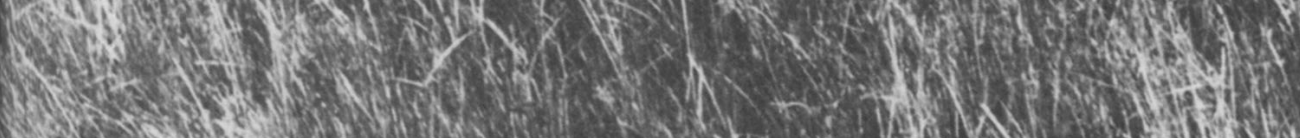
No ( Tho

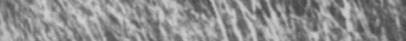
A moth (f) H.

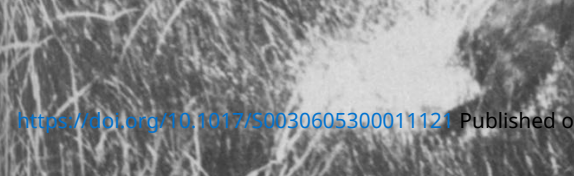
203060530001112 Published online by Cámbridge University Press

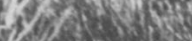
(1. 
Lake Chaya in the eastern floodplain where we have seen only scattered individuals. Secondly, in the Kalasa-Mukoso flats, the 1954 survey located 131 lechwe as opposed to 2292 in 1970. Reference to the 1954 flight map shows that their path did not cover the main wet-season concentration areas west of the Luapula, so that it is probable that the total of this sector in 1954 was at least as great as it is today.

Taking into account these two factors alone, and ignoring the possibility that the 1954 count may have failed to locate parts of the main southern floodplain population, it is likely that the total has decreased by at least 3800 since 1954 , and is still declining, particularly at the peripheries.

\section{Cause of the Decline}

What has caused the decline? Is it a decrease in the carrying capacity of the range as a result of the changing of the flooding regime, or is it due to uncontrolled hunting?

The only definite change in the flood regime was the rise of several feet in the 1930s. This certainly made some areas uninhabitable for people, particularly the Lunga Bank area in the central swamp, and may well have made parts of the range unsuitable for lechwe. But this rise does not account for the continuous decline both before and after this period. Since 1955, when flood level records were initiated, no trend can be seen, apart from two or three high-flood years following the exceptional rains of 1962 , so that, at present, there is no clear relationship visible between lechwe numbers and flood level.

Lechwe hunting was formerly an important part of the area's economy. Hughes (1933) wrote: 'All the islanders hunt the lechwe and sitatunga as their main source of living... (they) harry and drive the lechwe all day long, with nets and with dogs; also pole traps are set for them ... the lechwe are trapped each year in tens of thousands... Enormous loads of lechwe biltong are dried; more than they can eat. This is bartered for other produce, mostly barkcloth and iron implements, which they get from the inland tribes west of Bangweulu'.

Savory (1957) noted the extension of the lechwe's economic status as a trade commodity: 'Up till 1930, about 2000 people lived in the $\mathrm{Mbo} / \mathrm{Ncheta}$ area and did not apparently do any cultivation as they obtained all their requirements by bartering lechwe and fish. The fact that a lechwe was worth one shilling gives some idea of the numbers being killed... Since then, the accelerated decline of the lechwe has been synchronous with the development of the Copperbelt area of industrialisation. The problem is not one of a tribe killing meat for its own use, but as a profitable export'.

With the reduced population, the scale of hunting is clearly much smaller than formerly. Assuming a high annual increment of 20 per cent, an annual offtake in excess of 3200 would cause a decline in numbers. This would only involve an average daily offtake of between 8 and 9 animals, spread over 10,000 sq. km ( 4000 sq. miles) and shared among at least 15,000 people. It is impossible to estimate 
the hunting offtake, but the evidence available is consistent with a figure of this sort. It includes parties seen from the air hunting with nets, spears and dogs; skins and meat found in hut searches; large quantities of bones and carcase fragments found in villages; and large numbers of traps seen and collected in the floodplain.

If the cause of the reduction in numbers was the loss of favourable habitat due to a rise in the water level, signs of overutilisation of the remaining area would be expected. Here the Kafue lechwe situation provides a useful comparison, for a much larger population utilises the range at very high intensity, and on parts of the Kafue Flats, at the height of the floods, the grass cover is completely removed from large areas of flood line; a high proportion of the lechwe are in poor condition, many suffer from tuberculosis, and there is high adult mortality. None of these symptoms are evident in Bangweulu. In the watermeadows, where the main wet season concentrations occur, a short-growing, high-protein grass mat persists throughout the wet season. Furthermore, where lechwe are excluded by fenced plots, the watermeadow is immediately colonised by the 2.7 -metre high $(8 \mathrm{ft})$ shrub Sesbania sp., which may therefore be used as an indicator of under-utilised watermeadow. Large areas of Sesbania in the watermeadow zone suggest that at least 20 per cent of the potential watermeadow is under-utilised and has been colonised by this plant.

From the point of view of animal condition, the critical period is at the height of the floods when the water depth forces most of the lechwe out of the watermeadows into the low-protein peripheral grasslands. A sample of 50 animals caught and released at this time showed good condition, a good weight-to-body-length ratio and an intermediate blood urea level. Animal condition at this time is obviously a crucial point and further data are required, but existing evidence shows that the black lechwe are in much better condition than the Kafue lechwe.

We conclude, therefore, that the black lechwe are well below the carrying capacity of the range and that the cause of this is uncontrolled hunting.

It is possible to make a tentative estimate of the potential numbers of black lechwe by comparison with the Kafue situation. At the height of the floods, which is the most critical time of year as regards the lechwe's food supply, the Kafue lechwe are distributed in a narrow band along the floodline with a mean frequency of about 1000 per $\mathrm{km}$ of floodline (our surveys, 1970). In Bangweulu, the lengths of apparently suitable floodline are Kalasa Mukoso Flats, 30 $\mathrm{km}$, southern floodplain, $90 \mathrm{~km}$, eastern floodplain $40 \mathrm{~km}$ : total 160 $\mathrm{km}$.

Ignoring the northern floodplain as being too heavily settled for lechwe rehabilitation, it therefore seems reasonable to suggest that over 150,000 black lechwe could be supported by the remaining floodplains; that is, ten times as many as the present population.

In the two documented cases of African wildlife populations showing sustained increases as a result of hunting control, the white rhino in Zululand (Vincent, 1969) and the red lechwe in the Kafue 
National Park, Zambia (Grimsdell \& Bell, 1972), the annual rates of increase have been 10 per cent and 14 per cent respectively. At an annual rate of increase of 10 per cent a year, for example, it would take the black lechwe 20 years to reach 100,000 from the present 16,000 .

\section{Management Plan}

'All our political, economic, social, scientific and cultural planning must continue to be based on the creation of a Man-centred society' (Kaunda, 1968). This is the essence of the humanist policy on which Zambia's development is based; it is the guideline for the Bangweulu wildlife management plan that we are preparing. The local requirements are for protein and for employment; the national requirement is for diversification of the means of earning foreign exchange (Kaunda, 1969). Wildlife can fulfil all three requirements, through cropping, tourism and licensed hunting. But to justify this type of development it must be shown that these forms of land use do not compete with other, more immediately beneficial, forms.

The Bangweulu basin has two distinct land-use units: the flooded areas and the peripheral woodlands.

The flooded areas are a specialised environment where conventional settlement and agriculture are confined to the limited areas of dry ground, and domestic stock cannot survive in significant numbers. The only means of exploiting the high fertility of this large area is through specialised animals and plants-fish, lechwe, and rice. The fishery, which is the people's main source of food and income, cannot easily be developed (Inoue, 1971), but is perfectly compatible with lechwe exploitation, even though fishing requires that people have access to camps throughout the floodplain. Indeed, the presence of lechwe probably has a beneficial effect on fish productivity, by manuring the floodplain where the fish breed.

Rice, at present cultivated on a very small scale around some villages, could probably be developed on a large scale in the floodplain, but this would involve high investment, long-term development, and considerable social changes for the people in relation to production and marketing. It would also provide direct competition with both fishing and lechwe by habitat exclusion. We therefore suggest that, if large-scale rice projects are considered, they should be sited in the northern floodplain, where lechwe are virtually extinct and the human population more concentrated.

No lechwe should be cropped until the population has reached some 100,000. The ideal stocking level and offtake can only be estimated by monitoring the increase and then pilot cropping; but an offtake of 10 per cent from 100,000 would yield about 400 metric tons of meat annually. The mechanics and economics of the operation would have to be decided nearer the time, but it might have to be subsidised if it is to be controlled. If feasible, the cheapest, and possibly most effective method of cropping would be to issue annual quotas of hunting permits to local inhabitants.

In the meantime, the floodplain could earn an appreciable 
quantity of foreign currency from specialised photographic tourism and trophy hunting, based on the two rare antelopes, black lechwe and sitatunga, while the connoisseur would be attracted also by the unusual environment, the fishing and the birds, particularly the whale-headed stork. At present, with no accommodation available, tourism would have to be of the luxury tented-camp variety, aimed at the very high income bracket. It is difficult to estimate the revenue from this type of trade, but the amounts paid for licences of unusual trophies in other areas give some indication. In Eastern Europe, for example, a first-class red deer stag can cost a non-resident $£ 8000$, and at least ten clients a year could probably be found to pay prices of this order for such a sought-after trophy as the black lechwe.

The peripheral woodlands contrast sharply with the flooded areas in two ways. Firstly, the majority of the wooded areas will support settlement and agriculture, and most of the plateau will probably be so utilised in the foreseeable future, as a result of the stabilisation of shifting cultivation and consequent increase in the human population. This will exclude the wildlife from all areas other than completely protected reserves such as national parks. In this situation, wildlife preservation will be in direct conflict with shortterm human interests. Secondly the Brachystegia woodland of the plateau supports a varied fauna, but generally not very large biomasses; so that the economic justification for maintaining these national parks must be based on their tourist potential, rather than as a source of food.

COLLARED: The moment of release after being drugged, examined, weighed and collared. About 130 black lechwe have been caught in this way without any casualties.

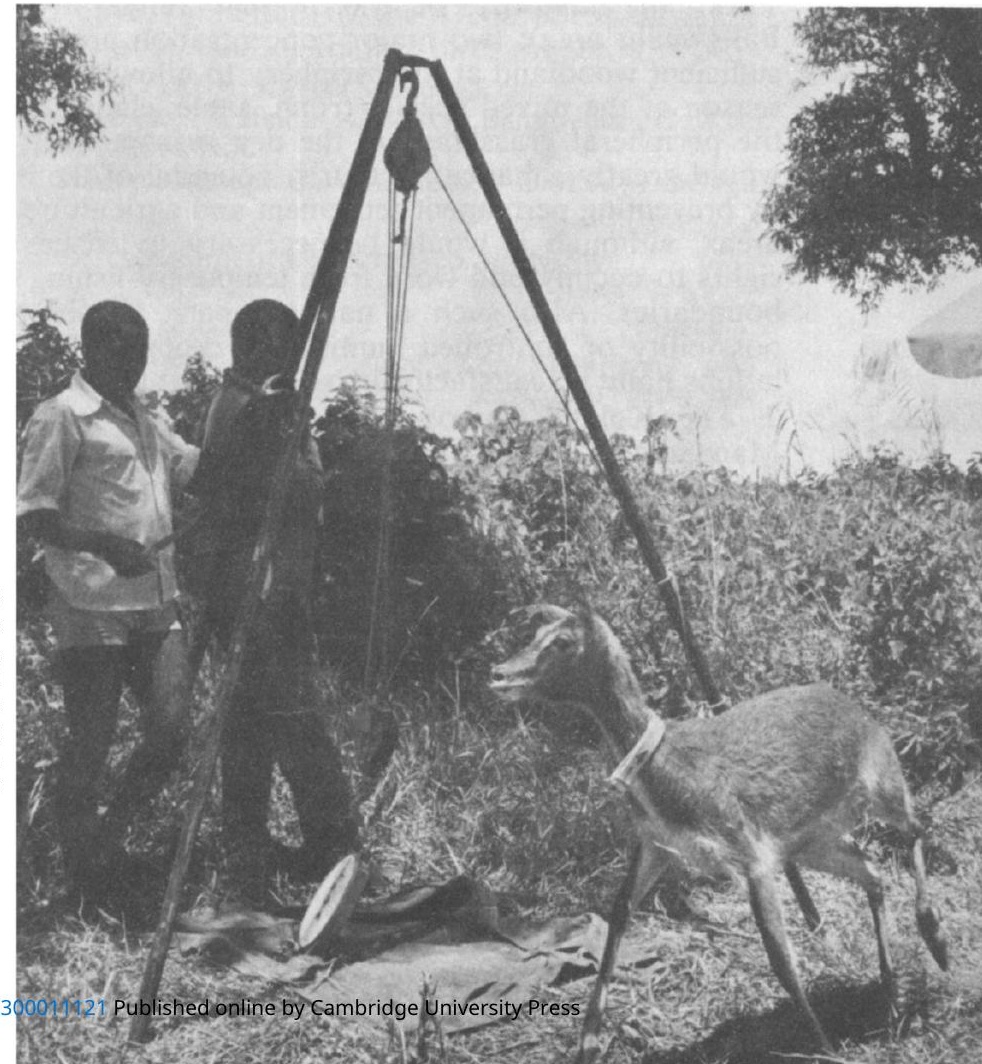


At present, the revenue from tourism in the Bangweulu area is nil, but we assume that it will increase manyfold in the next few years. The tourist industry is, of course, largely controlled by national and international considerations rather than local events, but its potential value must depend on the numbers of animals to be seen, and therefore also on the control of illegal hunting within the national parks.

\section{Public Relations and Law Enforcement}

The realisation of the wildlife potential in the Bangweulu basin as a natural resource depends entirely on the rehabilitation of the much depleted populations through public relations and law enforcement. The present legal position is that the black lechwe is a protected species throughout its range, most of which, apart from the Kalasa Mukoso Flats, is covered by three game management areas (in which settlement and limited hunting of specified species is permitted). Much of the peripheral woodland is covered by five game management areas, and parts (although only a small part of the black lechwe range - in the northern floodplain) are covered by three national parks.

\section{Our recommendations are:}

1. A new national park should be established on the periphery of the southern floodplain to include the main wet season concentration areas of black lechwe; the principal nesting area of the whale-headed stork; the majority of the present range of tsessebe (in the Bangweulu area); two major concentration areas of sitatunga, and sufficient woodland at the periphery to allow the survival in the wet season of the mixed species (roan, sable, eland, zebra, etc) that use the peripheral grasslands in the dry season. Such a national park would greatly enhance the tourist potential of the black lechwe area by preventing permanent settlement and agriculture in the peripheral areas, although it would be necessary to ensure the inhabitants' rights to occupy and work from temporary fishing camps within its boundaries. Also such a national park should not preclude the possibility of controlled hunting, or cropping, if the lechwe populations build up satisfactorily over the next two decades.

2. The Kalasa Mukoso Flats should be included in a Game Management Area for the protection of species other than lechwe.

3. Licensed hunting should be permitted in the Game Management Areas. In terms of public relations, licensed hunting, especially by non-residents, is an embarrassment, but it can be compatible with both allowing the wildlife populations to increase and ensuring that the inhabitants realise that wildlife exploitation is in their interests, provided that (a) no licences are issued until an increase in population sizes as a result of law enforcement can be demonstrated; (b) licences are issued only for those species whose rate of increase would be very little affected by a very limited number (e.g. 10) of annual permits. This list would include black lechwe and sitatunga, the two most numerous species in the Bangweulu Game 
Management Area; (c) very large licence fees are charged, at least $£ 3000$ for a black lechwe. No harm is done if no clients are prepared to pay such fees; (d) part (i.e. half) the licence fees are paid to a local authority for local development; (e) all the meat is handed over to a local authority (not to the hunting company, or Wildlife Department employees).

4. The Bangweulu catchment area should be safeguarded for the time being from physical and chemical interference, such as hydroelectric dams, large-scale irrigation schemes, and industrial effluents. At present no such interferences exist, but any major upset in the natural flood and silt regime would almost certainly be detrimental to both wildlife and fish in the swamps and floodplains. Chemical pollution could also be detrimental.

The law as it stands is adequate for most aspects' of the management plan. The overwhelming priority at present is enforcement to make it a reality, to halt the decrease in animal numbers and allow increases to begin. This is a formidable objective, requiring a complete change of attitude towards wildlife in the mass of the people. Such a task has rarely been successfully completed anywhere in the world, let alone in a developing country.

The Zambian Department of Wildlife, Fisheries and National Parks is well aware of the precarious state of the Bangweulu sector, and has estimated for a radical expansion of its effort there in the second 5-year Development Plan (1972-1977). It is also planned that the Bangweulu sector will become a separate Command. The proposals which we have submitted to the Department envisage dividing the single range of 30,000 sq. $\mathrm{km}$ into three ranges.

West: HQ. Samfya; Mansa G.M.A; Kalasa Mukoso Flats.

South: HQ. Chiundaponde; Kafinda G.M.A; Bangweulu G.M.A. Kasanka N.P.; Lavushi-Manda N.P.

East: HQ. Mbati; Eastern floodplain; Chambeshi G.M.A. Luwingu G.M.A; Isangano N.P.

It is proposed that the establishment be increased as follows:

$\begin{array}{cccccccccr} & \begin{array}{c}\text { Wild- } \\ \text { life } \\ \text { Camps }\end{array} & \begin{array}{c}\text { Wild- } \\ \text { life } \\ \text { Rang- } \\ \text { ers }\end{array} & \begin{array}{c}\text { Wild- } \\ \text { life } \\ \text { Guards }\end{array} & \begin{array}{c}\text { Carr- } \\ \text { iers. }\end{array} & \begin{array}{c}\text { Land } \\ \text { Rovers }\end{array} & \begin{array}{c}\text { Lorr- } \\ \text { ies }\end{array} & \begin{array}{c}\text { Lau- can- } \\ \text { nch. }\end{array} & \begin{array}{c}\text { Sm. } \\ \text { oes- }\end{array} & \begin{array}{r}\text { oes } \\ \text { on- }\end{array} \\ \text { West Existing } & 1 & - & 2 & 2 & - & - & - & - & - \\ \text { Proposed } & 8 & 1 & 20 & 20 & 1 & 1 & 1 & 2 & 4 \\ \text { South Existing } & 11 & 1 & 39 & 13 & 1 & - & - & 3 & 4 \\ \text { Proposed } & 15 & 1 & 50 & 50 & 3 & 1 & - & 2 & 8 \\ \text { East Existing } & 2 & - & 4 & 4 & - & - & - & - & 1 \\ \text { Proposed } & 10 & 1 & 30 & 30 & 1 & 1 & - & 2 & 10 \\ \text { Total Existing } & 14 & 1 & 45 & 19 & 3 & - & - & 3 & 5 \\ \text { Total Proposed } & 33 & 3 & 100 & 100 & 5 & 3 & 1 & 6 & 22\end{array}$

This scheme will take a lot of time and effort to put into practice. Even if the money and the will are there, serious shortcomings in the availability of materials, equipment, transport and trained personnel must be expected. In the meantime, since mid-1971, a series of externally based anti-poaching exercises have been carried out, 
resulting in considerable numbers of arrests. Since October 1971, these have been greatly assisted by the new Jet Ranger helicopter bought for the Wildlife Department by donations from English and American wildlife artists, Roan Consolidated Mines Ltd., Nchanga Consolidated Ltd., and others.

It is too early to tell whether this effort has been effective in halting the decline, and there is certainly no room for complacency, because for this large investment to show any return, the effort must be intensified and maintained for at least 20 years. The Wildlife Department must be commended, but ultimate success depends on the full cooperation and active support of the whole civil service, particularly the police, and of the mass of the people, who stand to benefit from the scheme in the long term.

\section{Acknowledgments}

We are grateful to Mr P.S.M. Berry of the Wildlife Department, for reading this paper and providing a photograph and to Mrs. S. Ramsay for typing this paper.

Both authors are members of the National Council for Scientific Research in Zambia.

\section{REFERENCES}

ALLEN, L.D.C. 1963. The lechwe (Kobus leche smithemani) of the Bangweulu Swamps. Puku 1, 1-8.

BRELSFORD, W.V. 1944. Vanishing lechwe of Bangweulu. The Field, London.

BRELSFORD, W.V. 1946. Fishermen of the Bangweulu Swamps. RhodesLivingstone Institute, Livingstone.

GRIMSDELL, J.J.R. \& BELL, R.H.V. 1970. Report of a census on the Kafue lechwe, 12th-15th October 1970. Cyclostyled report to the Wildlife Dept.

GRIMSDELL, J.J.R. \& BELL, R.H.V. 1972. Population growth of red lechwe, Kobus leche leche (Gray), in the Busanga Plain, Zambia. E. Afr. Wildl. J. $10,117-122$.

HOWE, G. 1954. Some notes on the Bangweulu area and its black lechwe population between December, 1922 and January, 1929 . In a report by C.W. Benson, 1955, GAM 10/Lechwe, Wildlife Department of Zambia files.

HUGHES, J.E. 1933. Eighteen years on Lake Bangweulu. The Field, London.

INOUE. K. 1971. Frame survey on Lake Bangweulu. Preliminary report. Typescript report, U.N./F.A.O. Central Fisheries Research Institute, Chilanga.

KAUNDA, K. 1968. Humanism in Zambia and a guide to its implementation. Government Printer, Lusaka.

KAUNDA, K. 1969. Report of the Second National Convention. Rural development, incomes, wages and prices in Zambia. Policy and machinery. Government Printer, Lusaka.

MARSHALL, H.C. 1957. Water transport in the Bangweulu Swamps. Northern Rhodesian Journal, 3 (3), 189-199.

PITMAN, C.R.S. 1934. A report on a faunal survey of Northern Rhodesia with special reference to game, elephant control and National Parks. Government Printer, Livingstone.

ROBINETTE, W.L. \& CHILD, G.F.T. 1964. Notes on biology of the lechwe (Kobus leche) Puku 2,84-117.

SAVORY, C.R. 1957. Conservation of lechwe for native nutrition in Northern Province. GAM. 10/Lechwe, Wildlife Department of Zambia files.

VESEY-FITZGERALD, D.F. 1955. The black lechwe and modern methods of wildlife conservation. Northern Rhodesia Journal, 2 (6), 25-32.

VINCENT, J. 1969. The status of the square-lipped rhinoceros, Ceratotherium simum simum (Burchell), in Zululand. Lammergeyer, 10. 12-21. 